\title{
Synthesis and X-Ray Crystal Structures of Trinuclear Nickel(II) Complexes Derived from Schiff Bases and Acetate Ligands with Biological Activity
}

\author{
Jin-Long Hou, ${ }^{*}$ Hong-Yuan Wu, Cheng-Bin Sun, Ye Bi and Wei Chen \\ College of Chemistry and Chemical Engineering, Qiqihar University, Qiqihar 161006, P. R. China \\ *Corresponding author: E-mail: houjinlong09@163.com
}

Received: 01-11-2020

\begin{abstract}
The reactions of $\mathrm{Ni}(\mathrm{OAc})_{2} 2 \mathrm{H}_{2} \mathrm{O}$ with Schiff base ligands 5-bromo-2-((cyclopentylimino)methyl)phenol $\left(\mathrm{HL}^{1}\right)$ and 5-bromo-2-(((2-(isopropylamino)ethyl)imino)methyl)phenol $\left(\mathrm{HL}^{2}\right)$ in methanol afforded two discrete trinuclear complexes $\left[\mathrm{Ni}_{3}\left(\mathrm{~L}^{1}\right)_{2}\left(\mu_{2}-\eta^{1}: \eta^{1}-\mathrm{OAc}\right)_{2}(\mathrm{DMF})_{2}(\mathrm{BrSal})_{2}\right](\mathbf{1})$ and $\left[\mathrm{Ni}_{3}\left(\mathrm{~L}^{2}\right)_{2}\left(\mu_{2}-\eta^{1}: \eta^{1}-\mathrm{OAc}\right)_{2}\left(\mu_{2}-\eta^{2}: \eta^{1}-\mathrm{OAc}\right)_{2}\right](2)$, where BrSal is the monoanionic form of 4-bromosalicylaldehyde. The complexes were characterized by elemental analysis, IR and UVVis spectroscopy. The crystal structures of the complexes have been determined by X-ray crystallography. In both complexes, the nickel atoms are in octahedral coordination geometries. The $\mathrm{L}^{1}$ ligand coordinates to the nickel atoms through the phenolate $\mathrm{O}$ and imino $\mathrm{N}$ atoms, and the $\mathrm{L}^{2}$ ligand coordinates to the nickel atoms through the phenolate $\mathrm{O}$, imino $\mathrm{N}$ and amino $\mathrm{N}$ atoms. The antimicrobial activities of the complexes were assayed.
\end{abstract}

Keywords: Nickel complexes; schiff bases; crystal structures; trinuclear complexes; antimicrobial activity

\section{Introduction}

Studies on supramolecular interaction and the self-assembly resulting from them have attracted remarkable attention in recent years. Schiff bases and their metal complexes exhibit biological activity as antibiotics, antiviral, antibacterial and antitumour agents because of their specific structures. ${ }^{1}$ Among Schiff bases, those derived from the mono-condensation of organic amines with carbonyl compounds, are a group of classical NO or NNO donor ligands. ${ }^{2}$ These ligands react readily with nickel salts to occupy its equatorial coordination sites whereas several anionic or neutral ligands can be coordinated to the fourth coordination site of the square plane to yield different type of complexes. ${ }^{3}$ Among the co-ligands, acetate has received remarkable attention because it can coordinate to the metal centers through versatile modes, such as monodentate, chelating, bidentate bridging, monoatomic bridging, chelating bridging, etc (Scheme 1). ${ }^{4}$ To combine Schiff bases and acetate ligands together in the complexes, a number of nickel complexes have been prepared. The complexes show interesting structures, biological, magnetic, and catalytic properties. ${ }^{5}$ However, it is still a great challenge to prepare acetate bridged multi-nuclear complexes with aiming structures. Herein, we report the synthesis and crystal structures of two new nickel(II) complexes, $\left[\mathrm{Ni}_{3}\left(\mathrm{~L}^{1}\right)_{2}\left(\mu_{2^{-}}\right.\right.$<smiles>[M]OC(C)=O</smiles>

Monodentate<smiles></smiles>

Chelating<smiles></smiles>

Bidentate bridging<smiles>[M]OC(C)=O</smiles>

Monoatomic bridging<smiles></smiles>

Chelating bridging

Scheme 1. Chelating modes of acetate ligand. 
$\left.\left.\eta^{1}: \eta^{1}-\mathrm{OAc}\right)_{2}(\mathrm{DMF})_{2}(\mathrm{BrSal})_{2}\right](\mathbf{1})$ and $\left[\mathrm{Ni}_{3}\left(\mathrm{~L}^{2}\right)_{2}\left(\mu_{2}-\eta^{1}: \eta^{1}\right.\right.$ $\left.\mathrm{OAc})_{2}\left(\mu_{2}-\eta^{2}: \eta^{1}-\mathrm{OAc}\right)_{2}\right]$ (2), where $\mathrm{L}^{1}=5$-bromo-2-((cyclopentylimino $)$ methyl $)$ phenolate, $\mathrm{L}^{2}=5$-bromo-2- $(((2$ -(isopropylamino)ethyl)imino)methyl)phenolate (Scheme 2), BrSal = 4-bromosalicylaldehyde.<smiles>Oc1cc(Br)ccc1/C=N/C1CCCC1</smiles><smiles>CC(C)NCC/N=C/c1ccc(Br)cc1O</smiles>

Scheme 2. $\mathrm{HL}^{1}$ and $\mathrm{HL}^{2}$

\section{Experimental Section}

\section{1. Materials and Physical Measurements}

4-Bromosalicylaldehyde, cyclopentylamine, $\mathrm{N}$-isopropylethane-1,2-diamine and nickel acetate were purchased from Sigma-Aldrich. All other chemicals were commercially available and used as received. Elemental analysis was carried out using model 2400 Perkin-Elmer $\mathrm{CHN}$ analyzer. Infrared spectra were collected by using $\mathrm{KBr}$ pellets on a Jasco-5300 FT-IR spectrophotometer. Electronic spectra were carried out with a Lambda 35 spectrometer.

\section{2. Preparation of Complex 1}

4-Bromosalicylaldehyde $(0.20 \mathrm{~g}, 10 \mathrm{mmol})$ and $\mathrm{cy}$ clopentylamine $(0.085 \mathrm{~g}, 10 \mathrm{mmol})$ were dissolved and stirred at ambient temperature in methanol $(30 \mathrm{~mL})$. Thirty minutes later, nickel acetate tetrahydrate $(0.50 \mathrm{~g}, 20$ mmol) was added to the solution. The color turned from yellow to deep green, and some insoluble residue was produced. Then, a few drops of DMF was added until the insoluble residue has disappeared. The reaction mixture was stirred for about $1 \mathrm{~h}$ and filtered. The filtrate was allowed to slow evaporate for a few days, generating green block shaped single crystals. Yield: $0.13 \mathrm{~g}(38 \%)$. Anal. Calcd for $\mathrm{C}_{48} \mathrm{H}_{54} \mathrm{Br}_{4} \mathrm{~N}_{4} \mathrm{Ni}_{3} \mathrm{O}_{12}: \mathrm{C}, 41.94 ; \mathrm{H}, 3.96 ; \mathrm{N}, 4.08$. Found: C, 41.72; $\mathrm{H}, 4.11 ; \mathrm{N}, 3.97$. IR data $\left(\mathrm{KBr} ; v_{\max }, \mathrm{cm}^{-1}\right): 3097$, 3052, 2936, 2868, 1643, 1581, 1517, 1456, 1429, 1408, 1285, $1183,1101,1064,914,863,785,672,601,553,451$. UV-Vis data in methanol $\left(\lambda, \mathrm{nm}\left(\varepsilon, \mathrm{L} \mathrm{mol}^{-1} \mathrm{~cm}^{-1}\right)\right]$ : $220(1.71 \times$ $\left.10^{4}\right), 245\left(1.34 \times 10^{4}\right), 273\left(9.17 \times 10^{3}\right), 380\left(3.70 \times 10^{3}\right)$.

\section{3. Preparation of Complex 2}

4-Bromosalicylaldehyde $(0.20 \mathrm{~g}, 10 \mathrm{mmol})$ and $\mathrm{N}$-isopropylethane-1,2-diamine $(0.102 \mathrm{~g}, 10 \mathrm{mmol})$ were dissolved and stirred at ambient temperature in methanol $(30 \mathrm{~mL})$. Thirty minutes later, nickel acetate tetrahydrate $(0.50 \mathrm{~g}, 20 \mathrm{mmol})$ was added to the solution. The color turned from yellow to deep green. The reaction mixture was stirred for about $1 \mathrm{~h}$ and filtered. The filtrate was al- lowed to slow evaporate for a few days, generating green block shaped single crystals. Yield: $0.21 \mathrm{~g}(43 \%)$. Anal. Calcd for $\mathrm{C}_{32} \mathrm{H}_{44} \mathrm{Br}_{2} \mathrm{~N}_{4} \mathrm{Ni}_{3} \mathrm{O}_{10}$ : C, 39.19; H, 4.52; N, 5.71 . Found: C, 38.96; H, 4.61; N, 5.82. IR data $\left(\mathrm{KBr} ; v_{\max }, \mathrm{cm}^{-1}\right)$ : $3107,3075,2935,2858,1627,1582,1550,1473,1430,1409$, $1396,1295,1188,1157,1102,987,862,785,667,610,565$, 463. UV-Vis data in methanol $\left(\lambda, \mathrm{nm}\left(\varepsilon, \mathrm{L} \mathrm{mol}^{-1} \mathrm{~cm}^{-1}\right)\right]$ : $222\left(1.56 \times 10^{4}\right), 240\left(1.70 \times 10^{4}\right), 265\left(5.32 \times 0^{3}\right), 335(4.81$ $\left.\times 10^{3}\right)$.

\section{4. X-ray Crystallography}

$\mathrm{X}$-ray data for the complexes were collected on a Bruker SMART 1000 CCD single crystal diffractometer at 298(2) K, equipped with a graphite monochromator and a Mo Ka fine-focus sealed tube $(\lambda=0.71073 \AA)$ by the $\omega$ scan method. Reflections were corrected for Lorentz and polarization effects, and for absorption by semi-empirical methods based on symmetry-equivalent and repeated reflections. The SMART software was used for data acquisition and the SAINT-PLUS software was used for data extraction. ${ }^{6}$ The absorption corrections were performed with the help of SADABS program. ${ }^{7}$ The structures were solved by direct methods and refined on $F^{2}$ by full-matrix leastsquares procedures. All non-hydrogen atoms were refined using anisotropic thermal parameters. Hydrogen atoms were included at idealized positions by using a riding model. The SHELX-97 programs were used for structure solution and refinement. ${ }^{8}$ Selected crystallographic data for the complexes are listed in Table 1.

Table 1. Crystal data and structure refinement parameters for complexes $\mathbf{1}$ and $\mathbf{2}$

\begin{tabular}{lcc}
\hline & 1 & 2 \\
\hline Formula & $\mathrm{C}_{12} \mathrm{H}_{14} \mathrm{BrCuN}_{3} \mathrm{OS}$ & $\mathrm{C}_{32} \mathrm{H}_{44} \mathrm{Br}_{2} \mathrm{~N}_{4} \mathrm{Ni}_{3} \mathrm{O}_{10}$ \\
$M$ & 391.8 & 980.7 \\
Temperature $(\mathrm{K})$ & $298(2)$ & $298(2)$ \\
Crystal system & Orthorhombic & Monoclinic \\
Space group & $P c a 2_{1}$ & $P 2_{1} / c$ \\
$a(\AA)$ & $12.875(1)$ & $11.4402(13)$ \\
$b(\AA)$ & $6.788(1)$ & $19.8179(17)$ \\
$c(\AA)$ & $16.531(1)$ & $8.6384(15)$ \\
$\beta\left({ }^{\circ}\right)$ & & $100.8150(10)$ \\
$V\left(\AA^{3}\right)$ & $1444.8(2)$ & $1923.7(4)$ \\
$Z$ & 4 & 2 \\
$D_{c}($ g/cm & \\
$\mu\left(\mathrm{mm}^{-1}\right)$ & 1.801 & 1.693 \\
$F(000)$ & 4.416 & 3.588 \\
Reflections collected & 780 & 996 \\
Independent reflections & 12900 & 10436 \\
$R_{\text {int }}$ & 2978 & 3581 \\
Reflections with & 0.0448 & 0.0998 \\
$F^{2}>2 \sigma\left(F^{2}\right)$ & 2644 & 1552 \\
$R_{1}\left[F^{2}>2 \sigma\left(F^{2}\right)\right]$ & & \\
$w R_{2}($ all data $)$ & 0.0405 & 0.0491 \\
Goodness-of-fit on $F^{2}$ & 0.1020 & 0.0907 \\
\hline & 1.082 & 0.931 \\
\hline
\end{tabular}




\section{Results and Discussion}

\section{1. Chemistry}

Both complexes were readily prepared by reacting nickel acetate tetrahydrate with Schiff base ligands. The elemental analysis data are consistent with the general molecular formulae of the complexes. In complex 1, the acetate ligands act as bidentate bridging groups. In complex $\mathbf{2}$, two acetate ligands act as bidentate bridging groups, and the other two act as chelating bridging groups. The complexes are soluble in common organic solvents like dimethyl sulphoxide, dimethylformamide, methanol, and ethanol.

\section{2. Infrared and Electronic Spectra of the Complexes}

In the spectra of the free Schiff bases $\mathrm{HL}^{1}$ and $\mathrm{HL}^{2}$, the bands at 1650 and $1645 \mathrm{~cm}^{-1}$, respectively, are assigned to the azomethine groups, $v_{\mathrm{C}=\mathrm{N}},{ }^{9}$ and the broad and weak absorptions at about $3430 \mathrm{~cm}^{-1}$ are assigned to the hydrox$\mathrm{yl}$ groups, $v_{\mathrm{O}-\mathrm{H}}$. In the complexes, the absence of the $\mathrm{O}-\mathrm{H}$ stretching and bonding vibrations indicates coordination through the phenolate groups. The $\mathrm{C}=\mathrm{N}$ stretches of the complexes are observed at lower frequencies (1643 and $1627 \mathrm{~cm}^{-1}$ ) when compared to the free Schiff bases. ${ }^{10}$ The phenolic $v(\mathrm{Ar}-\mathrm{O})$ in the free ligands exhibit bands at about $1270 \mathrm{~cm}^{-1}$. However, in the complexes it appears at about $1283 \mathrm{~cm}^{-1}$. The shift to higher wave number is an indication of $\mathrm{C}-\mathrm{O}-\mathrm{M}$ bond formation. The bands at about 1582 and $1408 \mathrm{~cm}^{-1}$ are assigned to the acetate ligands. ${ }^{4 a, 5 b}$ The occurrence of new bands in the $450-670 \mathrm{~cm}^{-1}$ region confirms the presence of metal-nitrogen and metal-oxygen bonds, respectively. ${ }^{11}$

In the electronic spectra of the free Schiff bases and the complexes, the absorption frequencies ascribed to the aromatic $\pi-\pi^{\star}$ and $n-\pi^{\star}$ transitions are located in the region 240-290 nm. ${ }^{12}$ In the electronic spectra of the complexes, the absorption centered at $380 \mathrm{~nm}$ for complex 1 and $335 \mathrm{~nm}$ for complex $\mathbf{2}$ are assigned to ligand-to-metal charge transfer. ${ }^{13}$

\section{3. Structure Description of Complex 1}

The molecular structure of complex $\mathbf{1}$ is depicted in Fig. 1. Bond parameters associated with the metal atom are listed in Table 2. The molecular structure is centrosymmetric with $\mathrm{Ni} 2$ atom on an inversion center. The structure shows a trinuclear complex consisting of three $\mathrm{Ni}$ atoms in a linear array, which is bridged by two acetate ligands and

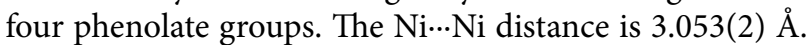
The Schiff base ligand coordinates to the $\mathrm{Ni}$ atoms through phenolate $\mathrm{O}$ and imino $\mathrm{N}$ atoms. The ligand 4-bromosalicylaldehyde coordinates to the $\mathrm{Ni}$ atoms through carbonyl $\mathrm{O}$ and phenolate $\mathrm{O}$ atoms. The acetate ligand acts as a bidentate bridging group. The Ni2 atom is located at the inversion centre of the complex in an octahedral geometry. This atom is coordinated by four phenolate $\mathrm{O}$ atoms from the Schiff base and 4-bromosalicylaldehyde ligands that form a plane and, near-perpendicularly to it, by two $\mathrm{O}$ atoms from two acetate bridging ligands that connect the central $\mathrm{Ni}$ atom to the outer $\mathrm{Ni}$ atoms. The greatest deviation of the bond angles from those expected for an ideal octahedral geometry is found for $\mathrm{O} 1-\mathrm{Ni} 2-\mathrm{O} 3$ with $79.3(3)^{\circ}$ and $\mathrm{O} 1-\mathrm{Ni} 2-\mathrm{O} 3 \mathrm{~A}$ with $100.7(3)^{\circ}$. The remaining bond angles are close to the ideal values for the octahedral coordination. The cis and trans coordinate bond angles for $\mathrm{Ni} 2$ are in the region $79.3(3)-100.7(3)^{\circ}$ and $180^{\circ}$. The terminal Ni1 atom is in an octahedral environment and is coordinated by the four donor atoms of the Schiff base and 4-bromosalicylaldehyde ligands in the equatorial plane, and by two $\mathrm{O}$ atoms from one bridging acetate group and one coordinated DMF ligand in the axial positions. The greatest deviations from an ideal octahedral geometry are found in the O2-Ni1-O6 $\left(84.9(3)^{\circ}\right)$ and in N1-Ni1-O2 $\left(100.8(4)^{\circ}\right)$ angles. The remaining bond angles are close to the ideal values for the octahedral coordination. The cis and trans coordinate bond angles for Nil are in the region 84.9(3)$100.8(4)^{\circ}$ and $168.8(3)-176.6(3)^{\circ}$. The $\mathrm{Ni}-\mathrm{O}$ and $\mathrm{Ni}-\mathrm{N}$ bond lengths are similar to those reported previously. ${ }^{14}$

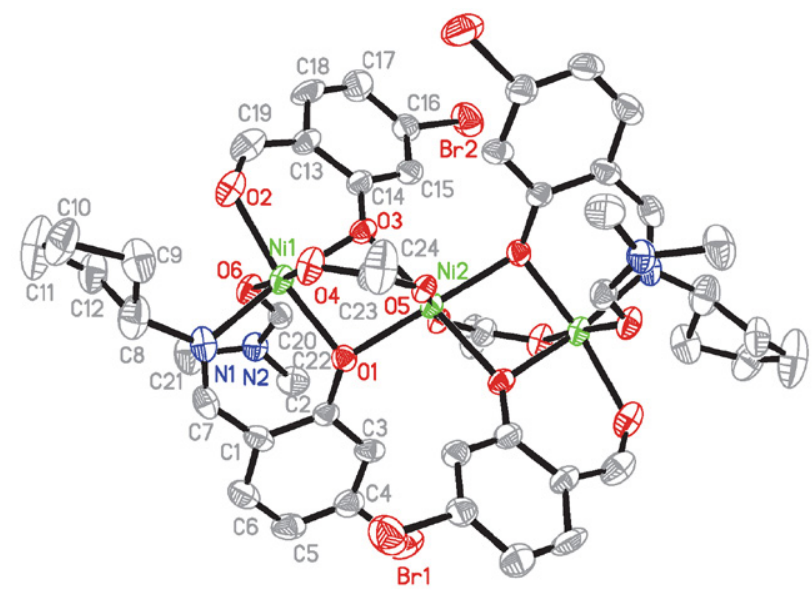

Figure 1. ORTEP diagram of complex 1 with thermal ellipsoids at $30 \%$ probability level. Selected bond lengths and angles are given in Table 2. Unlabeled atoms are related to the symmetry operation $1-$ $x, 1-y, 1-z$

\section{4. Structure Description of Complex 2}

The molecular structure of complex $\mathbf{2}$ is depicted in Fig. 2. Bond parameters associated with the metal atom are listed in Table 2. The molecular structure is centrosymmetric with $\mathrm{Ni} 2$ atom on an inversion center. The structure shows a trinuclear complex consisting of three $\mathrm{Ni}$ atoms in a linear array, which are bridged by four acetate ligands and two phenolate groups. The Ni...Ni distance is 3.043(2) ̊. The Schiff base ligand coordinates to the $\mathrm{Ni}$ atoms through phenolate $\mathrm{O}$, imino $\mathrm{N}$ and amino $\mathrm{N}$ atoms. Two of the acetate ligands act as bidentate bridging groups, and the other 
two act as chelating bridging groups. The Ni2 atom is located at the inversion centre of the complex in an octahedral geometry. This atom is coordinated by two phenolate $\mathrm{O}$ atoms from the Schiff base ligands and two $\mathrm{O}$ atoms from two bidentate bridging acetate groups that form a plane and, near-perpendicularly to it, by two $\mathrm{O}$ atoms from two chelating bridging acetate groups that connect the central $\mathrm{Ni}$ atom to the outer $\mathrm{Ni}$ atoms. The greatest deviation of the bond angles from those expected for an ideal octahedral geometry is found for $\mathrm{O} 1-\mathrm{Ni} 2-\mathrm{O} 2$ with $79.97(16)^{\circ}$ and O1-Ni2-O2A with $100.03(16)^{\circ}$. The remaining bond angles are close to the ideal values for the octahedral coordination. The cis and trans coordinate bond angles for $\mathrm{Ni} 2$ are in the region $79.97(16)-100.03(16)^{\circ}$ and $180^{\circ}$. The terminal $\mathrm{Nil}$ atom is in an octahedral environment and is coordinated by the three donor atoms of the Schiff base ligand and the $\mathrm{O} 2$ atom of the chelating bridging acetate group in the equatorial plane, and by $\mathrm{O} 3$ atom of the chelating bridging acetate group and $\mathrm{O} 4$ atom of the bidentate bridging acetate group in the axial positions. The greatest deviations from an ideal octahedral geometry are found in $\mathrm{O} 2-\mathrm{Ni1}-$ $\mathrm{O} 3\left(60.69(19)^{\circ}\right)$ and in $\mathrm{O} 2-\mathrm{Ni1}-\mathrm{N} 2\left(103.6(3)^{\circ}\right)$ angles. The remaining bond angles are close to the ideal values for the octahedral coordination. The cis and trans coordinate bond angles for Nil are in the region $60.69(19)-103.6(3)^{\circ}$ and 157.1(2) $-174.1(2)^{\circ}$. The $\mathrm{Ni}-\mathrm{O}$ and $\mathrm{Ni}-\mathrm{N}$ bond lengths are comparable to those of complex $\mathbf{1}$.

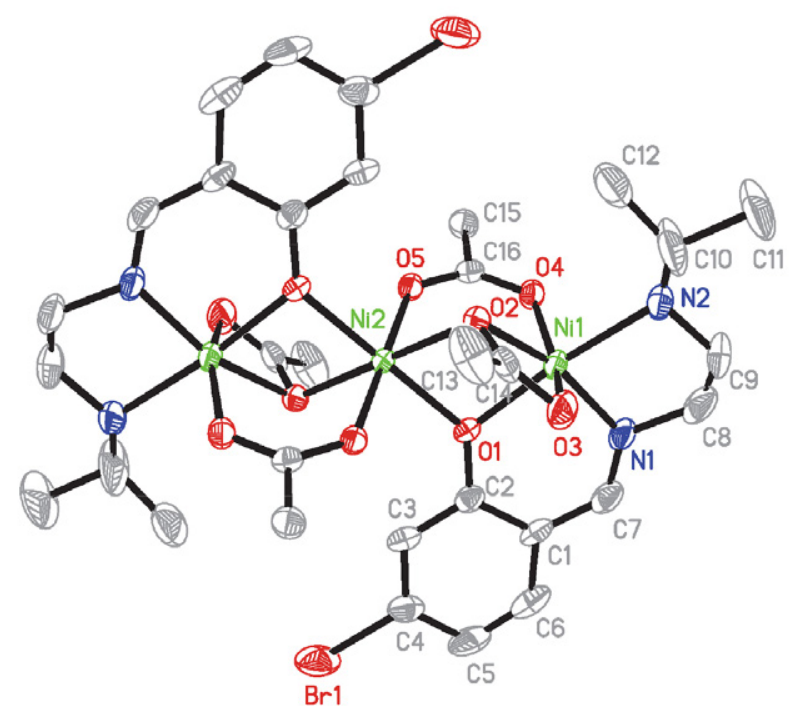

Figure 2. ORTEP diagram of complex 2 with thermal ellipsoids at $30 \%$ probability level. Selected bond lengths and angles are given in Table 2 . Unlabeled atoms are related to the symmetry operation 1 $-x, 1-y, 1-z$

\section{5. Antimicrobial Activity}

The complexes were assayed against the bacteria Escherichia coli and Salmonella typhi, and the fungi Aspergillus niger and Candida albicans by MIC (Minimum In- hibitory Concentration) method with three different concentrations of 100,50 and $25 \mu \mathrm{g} .{ }^{15}$ The activity was also assayed for the free Schiff bases, the pure solvent DMF and the standard gentamycine for each of antibacterial and flucanazole for antifungal cultures. Final adjustments were made using optical density measurement for bacteria (absorbance 0.05 at $580 \mathrm{~nm}$ ). The zones of inhibition in millimeter for the compounds are presented in Table 3 . The two complexes have similar activities against the bacteria and fungi, and they are more susceptible toward bacterial cells than fungicidal cells. In general, both complexes have better activities than the free Schiff bases. The trends are in

Table 2. Selected bond distances $(\AA)$ and angles $\left({ }^{\circ}\right)$ for complexes 1 and 2

\begin{tabular}{lcll}
\hline & & & \\
\hline Bond distances & & & \\
Ni1-N1 & $2.035(10)$ & Ni1-O1 & $2.014(7)$ \\
Ni1-O2 & $2.062(9)$ & Ni1-O3 & $2.023(7)$ \\
Ni1-O4 & $2.023(7)$ & Ni1-O6 & $2.125(8)$ \\
Ni2-O5 & $2.022(7)$ & Ni2-O1 & $2.048(6)$ \\
Ni2-O3 & $2.071(6)$ & & \\
Bond angles & & & \\
O1-Ni1-O4 & $91.2(3)$ & O1-Ni1-O3 & $81.3(3)$ \\
O4-Ni1-O3 & $90.9(3)$ & O1-Ni1-N1 & $89.7(4)$ \\
O4-Ni1-N1 & $93.2(4)$ & O3-Ni1-N1 & $170.2(4)$ \\
O1-Ni1-O2 & $168.8(3)$ & O4-Ni1-O2 & $92.0(3)$ \\
O3-Ni1-O2 & $88.0(3)$ & N1-Ni1-O2 & $100.8(4)$ \\
O1-Ni1-O6 & $92.1(3)$ & O4-Ni1-O6 & $176.6(3)$ \\
O3-Ni1-O6 & $90.5(3)$ & N1-Ni1-O6 & $85.8(4)$ \\
O2-Ni1-O6 & $84.9(3)$ & O5-Ni2-O5A & 180 \\
O5-Ni2-O1A & $92.3(3)$ & O5-Ni2-O1 & $87.7(3)$ \\
O1-Ni2-O1A & 180 & O5-Ni2-O3A & $90.7(3)$ \\
O1-Ni2-O3A & $100.7(3)$ & O5-Ni2-O3 & $89.3(3)$ \\
O1-Ni2-O3 & $79.3(3)$ & O3-Ni2-O3A & 180 \\
\hline 2 & & & \\
\hline Bond distances & & & \\
Ni1-N1 & $1.976(6)$ & Ni1-N2 & $2.152(8)$ \\
Ni1-O1 & $2.010(4)$ & Ni1-O2 & $2.100(4)$ \\
Ni1-O3 & $2.201(6)$ & Ni1-O4 & $2.015(4)$ \\
Ni2-O5 & $2.009(4)$ & Ni2-O1 & $2.057(4)$ \\
Ni2-O2 & $2.117(4)$ & & 189.91 \\
Bond angles & & & \\
N1-Ni1-O1 & $90.5(3)$ & N1-Ni1-O4 & $100.9(2)$ \\
O1-Ni1-O4 & $93.11(17)$ & N1-Ni1-O2 & $159.8(2)$ \\
O1-Ni1-O2 & $81.45(16)$ & O4-Ni1-O2 & $98.00(18)$ \\
N1-Ni1-N2 & $83.7(3)$ & O1-Ni1-N2 & $174.1(2)$ \\
O4-Ni1-N2 & $89.3(2)$ & O2-Ni1-N2 & $103.6(3)-$. \\
N1-Ni1-O3 & $101.4(2)$ & O1-Ni1-O3 & $91.91(19)$ \\
O4-Ni1-O3 & $157.1(2)$ & O2-Ni1-O3 & $60.69(19)$ \\
N2-Ni1-O3 & $88.0(3)$ & O5-Ni2-O5A & 180 \\
O5-Ni2-O1 & $90.09(16)$ & O5-Ni2-O1A & $89.91(16)$ \\
O1-Ni2-O2 & 180 & O5-Ni2-O2A & $90.16(17)$ \\
\hline & $79.97(16)$ & O2-Ni2-O2A & 180 \\
\hline
\end{tabular}

Symmetry operation for A: $1-x, 1-y, 1-z$. 
Table 3. Antimicrobial activities of the compounds (zone of inhibition in $\mathrm{mm}$ )

\begin{tabular}{lcccc}
\hline Compound & $\begin{array}{c}\text { Bacteria } \\
\text { Escherichia coli }\end{array}$ & $\begin{array}{c}\text { Fungi } \\
\text { Salmonella typhi }\end{array}$ & Aspergillus niger & Candida albicans \\
\hline $\mathbf{1}$ & 29 & 31 & 15 & 18 \\
$\mathbf{2}$ & 30 & 30 & 16 & 18 \\
$\mathrm{HL}^{1}$ & 15 & 11 & - & - \\
$\mathrm{HL}^{2}$ & 13 & 12 & - & - \\
Gentamycine & 28 & 28 & - & - \\
Flucanazole & - & - & 23 & 23 \\
DMF & 12 & 14 & 12 & 12 \\
\hline
\end{tabular}

The concentration is $100 \mu \mathrm{g} \mathrm{L}-1$.

accordance with the literature that metal complexes are more active in the biological potential than the ligands used in the synthesis. ${ }^{16}$ When comparing the antimicrobial activity of the studied complexes to those of reference antibiotics, the inhibitory ability is found to be good. For example, the two complexes have similar or even higher activity on the bacteria Escherichia coli and Salmonella typhi than gentamycine, and have effective activity on Aspergillus niger and Candida albicans, which is seldom seen in the literature. The results indicate that the two complexes can possibly be used in the treatment of diseases caused by the bacteria that were tested.

\section{Conclusion}

A pair of novel acetato-bridged nickel(II) complexes derived from the Schiff base ligands 5-bromo-2-((cyclopentylimino)methyl)phenol and 5-bromo-2-(((2-(isopropylamino)ethyl)imino)methyl)phenol were prepared. Single crystal structures of the complexes indicates that both complexes are trinuclear nickel(II) compounds. All of the nickel atoms in the complexes are in octahedral coordination geometries. The complexes have good antimicrobial activities against Escherichia coli, Salmonella typhi, Aspergillus niger and Candida albicans.

\section{Supplementary Material}

CCDC Nos. 1974759 (1) and 1974760 (2) contain the supplementary crystallographic data for this paper. These data can be obtained free of charge from the Cambridge Crystallographic Data Centre via www.ccdc.cam. ac.uk/data request/cif. Crystal data and details of the data collection and refinement for the complexes are collected in Table 1.

\section{References}

1. (a) H. Keypour, F. Forouzandeh, S. Salehzadeh, F. Hajibabaei, S. Feizi, R. Karamian, N. Ghiasi, R. W. Gable, Polyhedron 2019, 170, 584-592; DOI:10.1016/j.poly.2019.06.023 (b) L. Saghatforoush, K. Moeini, S. A. Hosseini-Yazdi, Z. Mardani, A. Bakhtiari, A. Hajabbas-Farshchi, S. Honarvar, M. S. M. Abdelbaky, Polyhedron 2019, 170, 312-324; DOI:10.1016/j.poly.2019.05.057

(c) S. C. Manna, S. Mistri, A. Patra, M. K. Mahish, D. Saren, R. K. Manne, M. K. Santra, E. Zangrando, H. Puschmann, Polyhedron 2019, 171, 77-85; DOI:10.1016/j.poly.2019.06.049

(d) M. S. S. Adam, O. M. El-Hady, F. Ullah, RSC Advances 2019, 9, 34311-34329; DOI:10.1039/C9RA06816C

(e) K. Dankhoff, M. Gold, L. Kober, F. Schmitt, L. Pfeifer, A. Durrmann, H. Kostrhunova, M. Rothemund, V. Brabec, R. Schobert, Dalton Trans. 2019, 48, 15220-15230.

DOI:10.1039/C9DT02571E

2. (a) H.-Y. Qian, Acta Chim. Slov. 2019, 66, 995-1001; DOI:10.4149/neo_2019_190112N36

(b) H. Y. Qian, Russ. J. Coord. Chem. 2018, 44, 32-38; DOI:10.1134/S1070328418010074

(c) H.-Y. Qian, Inorg. Nano-Met. Chem. 2018, 48, 615-619. DOI:10.1080/24701556.2019.1567542

3. (a) K. Ghosh, S. Banerjee, S. Chattopadhyay, CrystEngComm 2019, 21, 6026-6037; DOI:10.1039/C9CE00922A

(b) H. Kargar, V. Torabi, A. Akbari, R. Behjatmanesh-Ardakani, A. Sahraei, M. N. Tahir, Struct. Chem. 2019, 30, 2289 2299; DOI:10.1007/s11224-019-01350-9

(c) R. Ogawa, T. Suzuki, M. Hirotsu, N. Nishi, Y. Shimizu, Y. Sunatsuki, Y. Teki, I. Kinoshita, Dalton Trans. 2019, 48, 13622-13629. DOI:10.1039/C9DT03007G

4. (a) B.-H. Ye, X.-Y. Li, I. D. Williams, X.-M. Chen, Inorg. Chem. 2002, 41, 6426-6431; DOI:10.1021/ic025806+

(b) U. Kumar, J. Thomas, N. Thirupathi, Inorg. Chem. 2010, 49, 62-72. DOI:10.1021/ic901100z

5. (a) A. Majumder, G. M. Rosair, A. Mallick, N. Chattopadhyay, S. Mitra, Polyhedron 2006, 25, 1753-1762;

DOI:10.1016/j.poly.2005.11.029

(b) P. Li, M. J. Niu, M. Hong, S. Cheng, J. M. Dou, J. Inorg. Biochem. 2014, 137, 101-108; DOI:10.1016/j.jinorgbio.2014.04.005

(c) M. Salehi, F. Rahimifar, M. Kubicki, A. Asadi, Inorg. Chim. Acta 2016, 443, 28-35; DOI:10.1016/j.ica.2015.12.016

(d) X.-S. Zhou, X.-S. Cheng, Y.-N. Li, F.-Y. Tian, F.-Y. Xu, Z.L. You, Chin. J. Inorg. Chem. 2013, 29, 397-402;

(e) J.-C. Zhang, Y. Lu, X.-H. Li, Z.-L. You, Chin. J. Inorg. Chem. 2012, 28, 1259-1264. 
6. SMART version 5.63 and SAINT-PLUS version 6.45, Bruker-Nonius Analytical X-ray Systems Inc., Madison, WI, USA, 2003.

7. G. M. Sheldrick. SADABS, Empirical Absorption Correction Program, University of Göttingen, Göttingen, Germany, 1997.

8. G. M. Sheldrick. SHELX-97, Structure Determination Software, University of Göttingen, Göttingen, Germany, 1997.

9. (a) M. Zhang, D.-M. Xian, H.-H. Li, J.-C. Zhang, Z.-L. You, Aust. J. Chem. 2012, 65, 343-350;

DOI:10.1071/CH11424

(b) M. Duan, Y. Li, L. Xu, H. Yang, F. Luo, Y. Guan, B. Zhang, C. Jing, Z. You, Inorg. Chem. Commun. 2019, 100, 27-31. DOI:10.1016/j.inoche.2018.12.009

10. (a) H.-Y. Qian, N. Sun, Transition Met. Chem. 2019, 44, 501506; DOI:10.1007/s11243-018-00296-X

(b) H. Y. Qian, Russ. J. Coord. Chem. 2017, 43, 780-786. DOI:10.1134/S1070328417110070

11. H.-Y. Qian, Inorg. Nano-Met. Chem. 2018, 48, 461-466. DOI:10.1080/24701556.2019.1569689

12. H. Liu, D. Niu, Z. Lu, J. Coord. Chem. 2009, 62, 3763-3771. DOI:10.1080/00958970903159131
13. A. Ray, D. Sadhukhan, G. M. Rosair, C. J. Gomez-Garcia, S. Mitra, Polyhedron 2009, 28, 3542-3550.

DOI:10.1016/j.poly.2009.07.017

14. (a) M. K. Taylor, J. Reglinski, D. Wallace, Polyhedron 2004, 23, 3201-3209; DOI:10.1016/j.poly.2004.10.002

(b) R. Sanyal, S. K. Dash, P. Kundu, D. Mandal, S. Roy, D. Das, Inorg. Chim. Acta 2016, 453, 394-401;

DOI:10.1016/j.ica.2016.08.047

(c) L. Rigamonti, A. Forni, Inorg. Chim. Acta 2018, 473, 216222. DOI:10.1016/j.ica.2018.01.007

15. M. A. Phaniband, S. D. Dhumwad, J. Coord. Chem. 2009, 62, 2399-2410. DOI:10.1080/00958970902803341

16. (a) L.-W. Xue, H.-J. Zhang, P.-P. Wang, Acta Chim. Slov. 2019, 66, 190-195; DOI:10.17344/acsi.2018.4868

(b) G.-X. He, L.-W. Xue, Q.-L. Peng, P.-P. Wang, H.-J. Zhang, Acta Chim. Slov. 2019, 66, 570-575;

(c) S. Daravath, A. Rambabu, N. Vamsikrishna, N. Ganji, S. Raj, J. Coord. Chem. 2019, 72, 1973-1993;

DOI:10.1080/00958972.2019.1634263

(d) M. A. Shaheen, W. Xiao, M. Aziz, A. Karim, M. Saleem, M. Mustaqeem, T. Mehmood, M. N. Tahir, A. Sltan, A. Simair, C. Lu, Russ. J. Gen. Chem. 2019, 89, 1691-1695. DOI:10.1134/S1070363219080231

\section{Povzetek}

$\mathrm{Z}$ reakcijo $\mathrm{Ni}(\mathrm{OAc})_{2} \cdot 2 \mathrm{H}_{2} \mathrm{O}$ s Schiffovo bazo 5-bromo-2-((ciklopentilimino)metil)fenolom (HL $\left.{ }^{1}\right)$ in 5-bromo-2-(((2-(izopropilamino)etil)imino)metil)fenolom $\left(\mathrm{HL}^{2}\right) \quad \mathrm{v}$ metanolu smo izolirali dva diskretna trijedrna kompleksa $\left[\mathrm{Ni}_{3}\left(\mathrm{~L}^{1}\right)_{2}\left(\mu_{2}-\eta^{1}: \eta^{1}-\mathrm{OAc}\right)_{2}(\mathrm{DMF})_{2}(\mathrm{BrSal})_{2}\right](\mathbf{1})$ in $\left[\mathrm{Ni}_{3}\left(\mathrm{~L}^{2}\right)_{2}\left(\mu_{2}-\eta^{1}: \eta^{1}-\mathrm{OAc}\right)_{2}\left(\mu_{2}-\eta^{2}: \eta^{1}-\mathrm{OAc}\right)_{2}\right]$ (2), kjer je BrSal monoanionska oblika 4-bromosalicilaldehida. Kompleksa sta bila okarakterizirana z elementno analizo, IR in UV-Vis spektroskopijo. Strukture kompleksov so bile določene $\mathrm{z}$ rentgensko monokristalno difrakcijo. V obeh kompleksih je nikljev atom $\mathrm{v}$ oktaedrični koordinaciji. Ligand $\mathrm{L}^{1}$ se koordinira na nikljev atom preko fenolatnega $\mathrm{O}$ in imino $\mathrm{N}$ atoma, ligand $\mathrm{L}^{2}$ se koordinira na nikljev atom preko fenolatnega $\mathrm{O}$, imino $\mathrm{N}$ in amino $\mathrm{N}$ atomov. Določena je bila tudi antimikrobna aktivnost kompleksov.

Except when otherwise noted, articles in this journal are published under the terms and conditions of the Creative Commons Attribution 4.0 International License 